
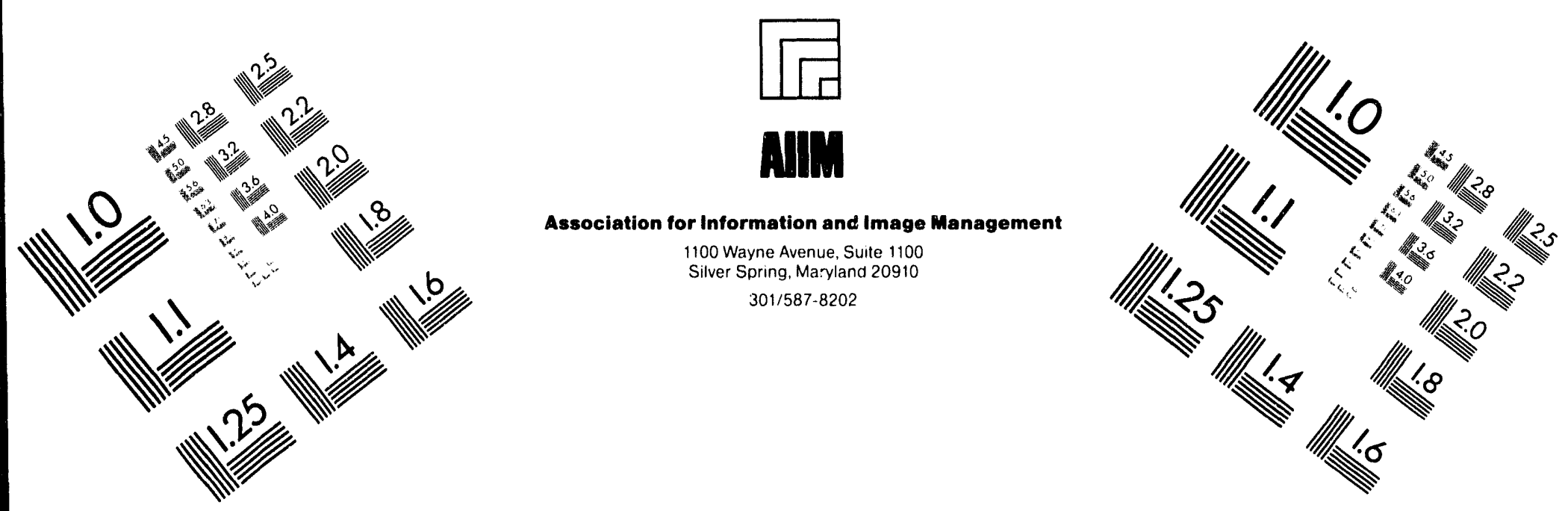

\title{
Centimeter
}

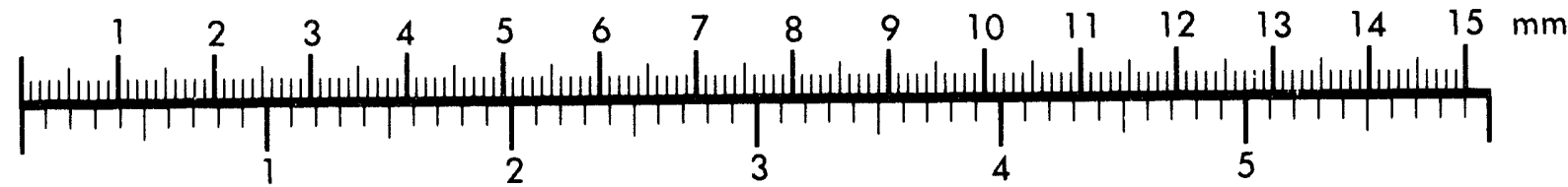

Inches
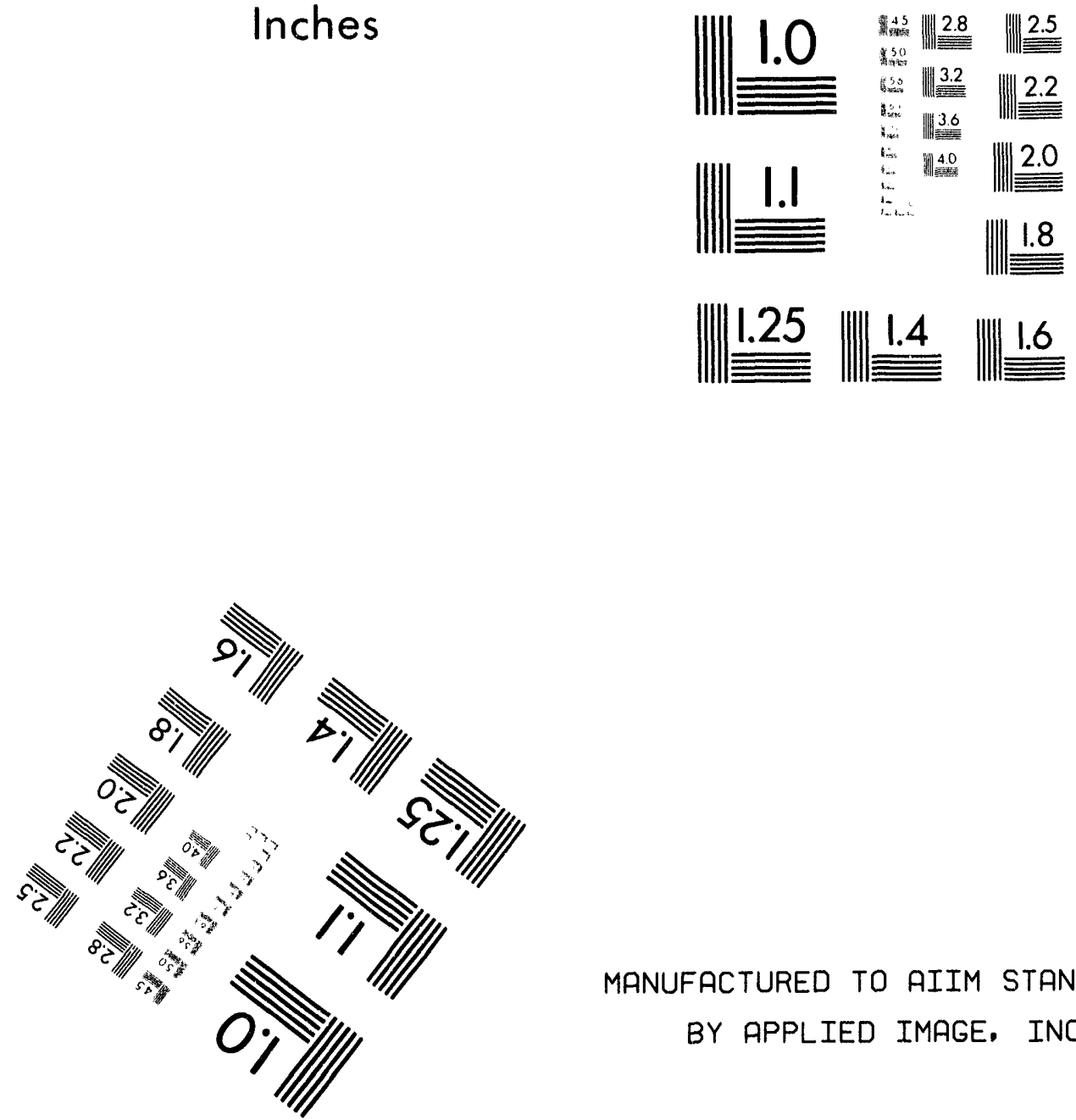

MANUFACTURED TO AIIM STANDARDS

BY APPLIED IMAGE, INC.

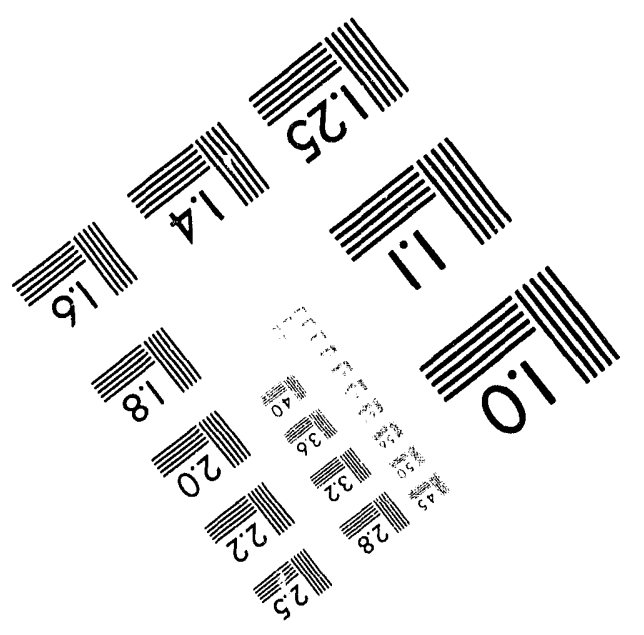





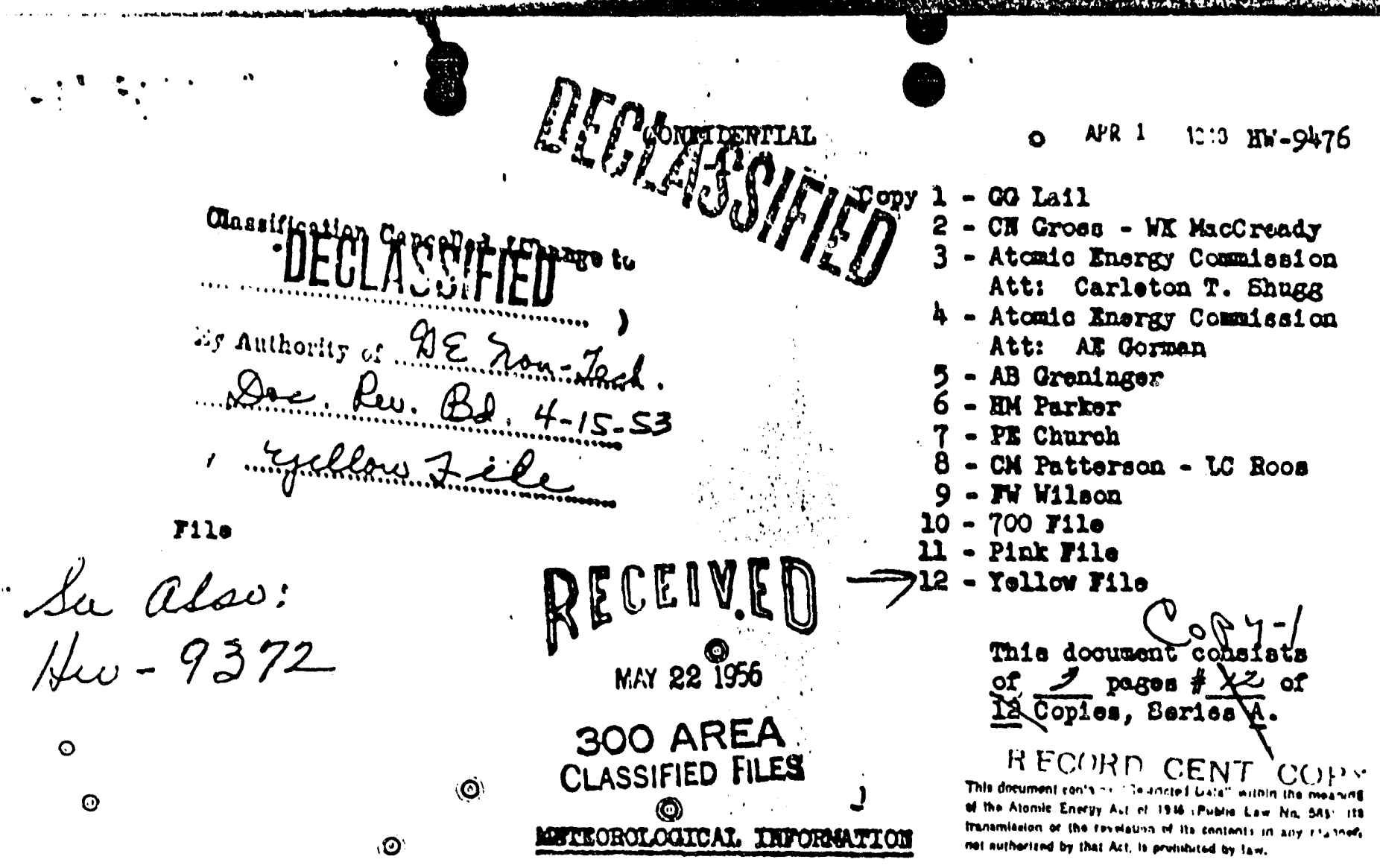

In anowis to your quostiane I suegest the follorlag procoduros:

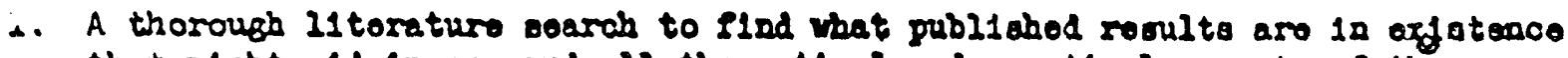
that algt ald in ang and all thoorotical and priot1cal sopoots of tho problan. Suoh rould inolndo tuds os of:

2. Shlfting of particlos on the mursace.

Tranoport (wind) of and cralns. Tharo is a Largo litorature an this

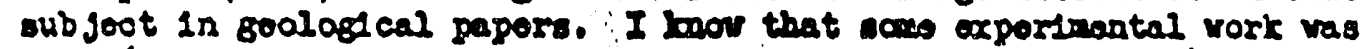
dano (by the Inst1tato of Motoorologs, Uni roralty of Ch1 caso) an tho enount of transport of and at marlone $10 \mathrm{mols}$ (01000 to ourfaco) in

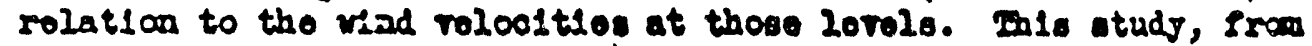
date taken in nid-Septeaber 2942, 1noluded ales of partiolos. I an not auro that the aboro papor bal boen publlahud.

2. Shiftias of particlos rron tho axpaco into tho alr.

a. Wind reloolty at rarlowe holote abovo the suriace (and ruto of chengs af rsloolty) is th rospeot to both stable and anstablo

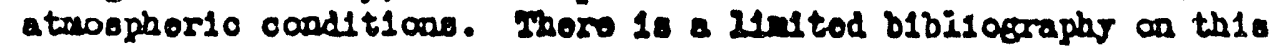
oubjoct; tho bost I koon 1s Celgor, R. "Das blima dex Bodomation

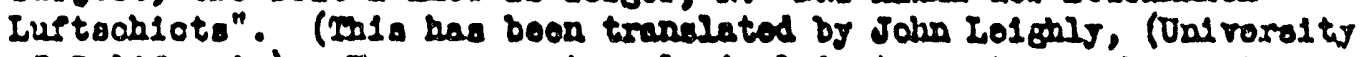
of Callfornia). Borroror, notooralogd oal instrimontation nas not roachod the stago jot onah that roloolts (both rortlaal and horleantal) can bo mado in tho 2njors larolriag tho tranoltion fran at rent on tho urtace to alrborno.

b. A100 sugesost that soarah bo ado in tho $\$ 101 d$ of ocaroot1an and

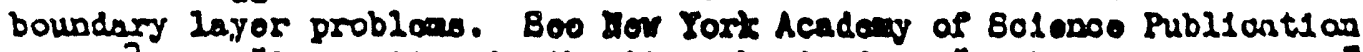
Ilo. ? "Costoction in the Atrosphorfo Oovan". Thore aro a

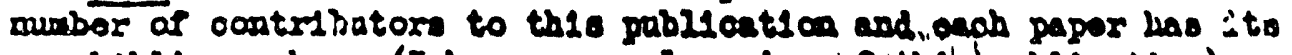
ora blbllography. (I bavo sorosal ooplopu pe thlib publication). 


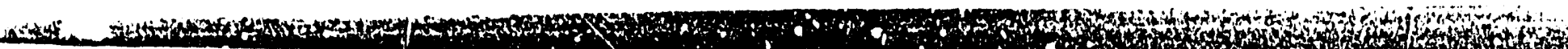

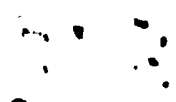

(1)

PEC-F120

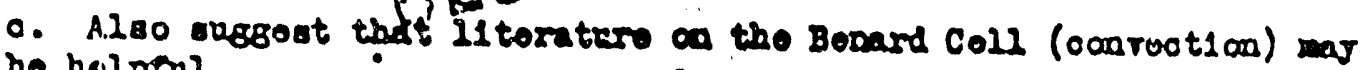
bo hollpral.

BH -9476

(\$)

(c)

)

10

3. Erforst of 8120 part10le on tranoport through nose.

Mot In my (1)

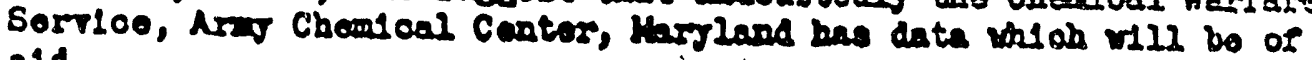
ald.

4. Dilution ifth 1noroaning alstanos of horl zontal tranoport.

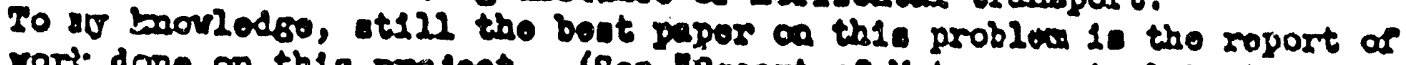
rori: done on this project. (Bow "Roport ar Motoorologdoal sootlon ar

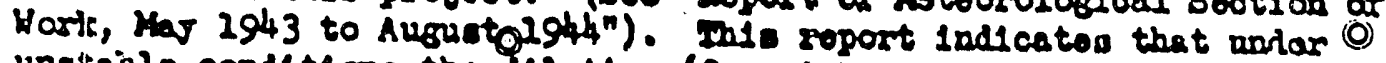
unstaiolo oonditlone the dilation (far alrborno aizrosolo of nopllgiblo

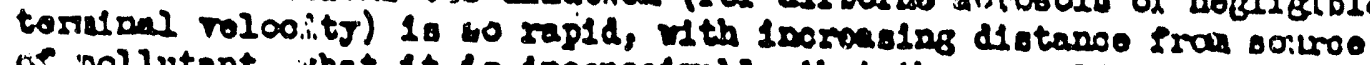
of pollutant, that 1t 10 10000001 rable that thoro could go an doloterlous conoontration dorolop at a diatanoo of 2 ulis fran a

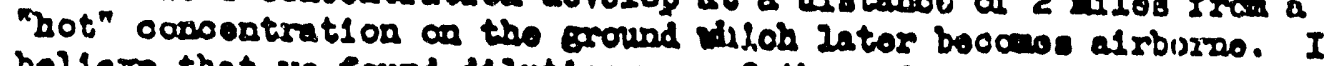

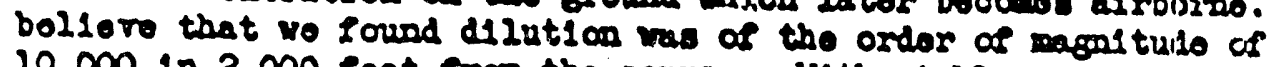
10,000 in 2,000 foot fran the soverse. With atablo conditions no

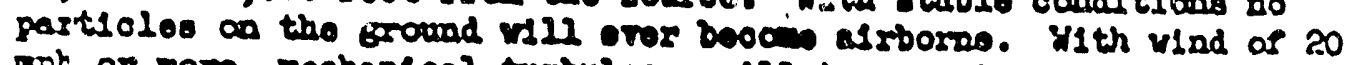

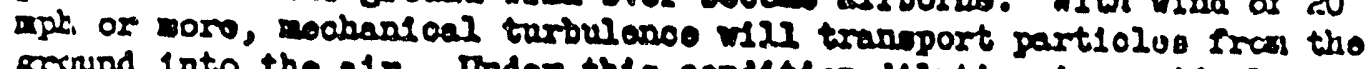

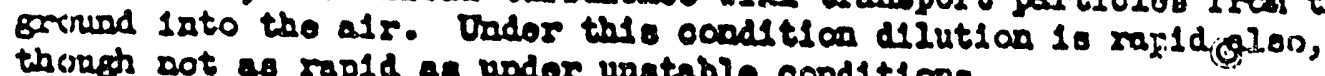
thoragh bot as rap1d as undor unatablo condit1 ons.

5. Altsitade to whils partitiles an 100.

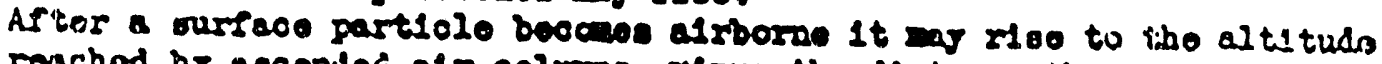
raschod bs accopdoc als oolwens, mime the distanoe the peirtiolo

- rall. whilo in the arconding alr. Partiolos of nogligdblil rato of fall could ascond 10,000 to 15,000 foot in wawn (thormal carroot 1 an) and portaps, though raroly, 2,000 to 3, no0 foot, in wintor (mochnaloal turbuladoc).

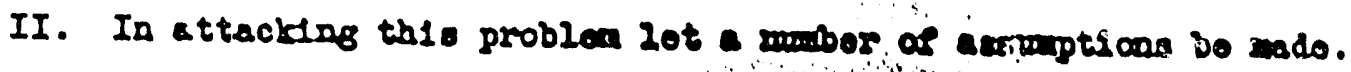

1. Wriat tho mubor of particles bolos eseabargod vall dooroeso to tho vastahing polat within a for wonthe."

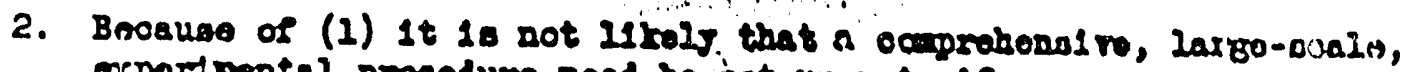
coportrontal procoduro nood bo bot up jot, 19 over.

3. That the part10100 prosent, and those got to full, wast 1:0 rous rod

0

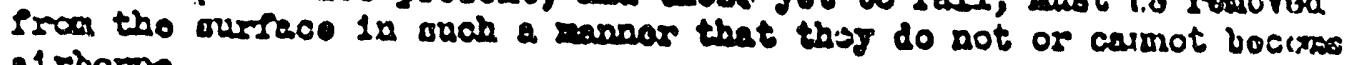
at roorno.

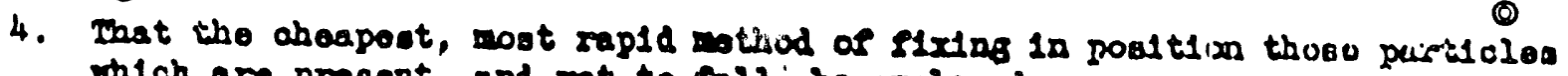
whlab are prooont, and roti to rall; hi emplojed

○

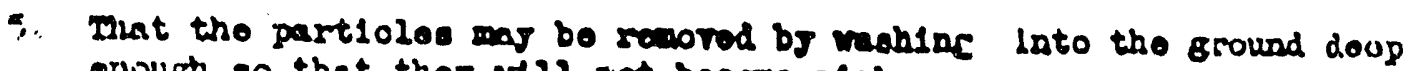

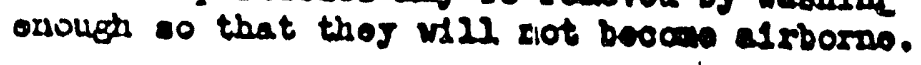

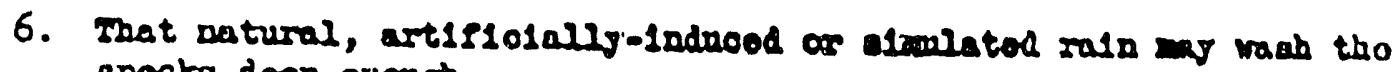
spocko doop oxwough.

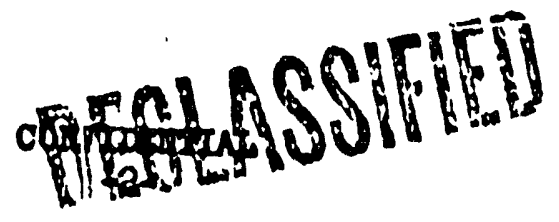




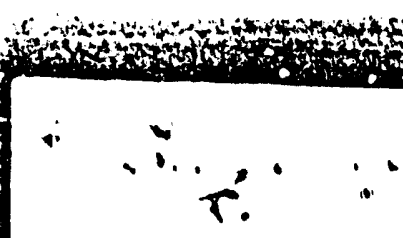

PXC-I10

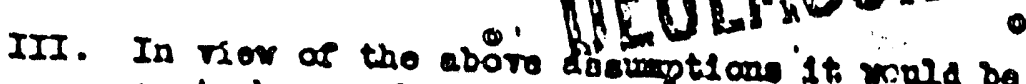

ald bo woll to oonduot some trial.

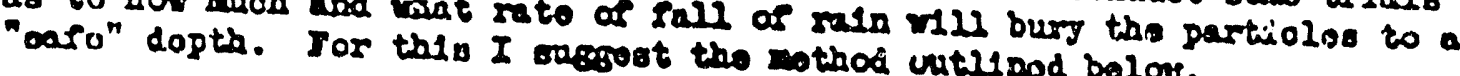

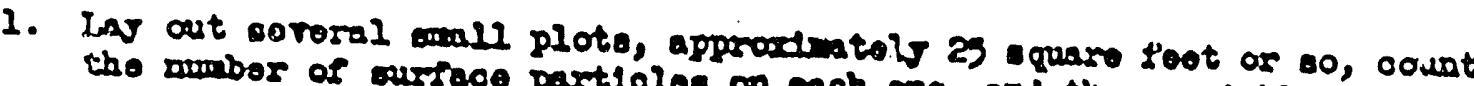

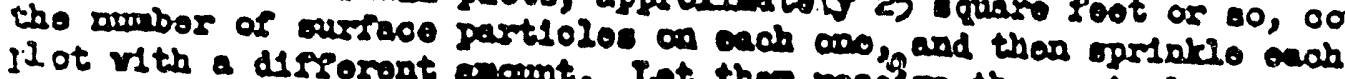

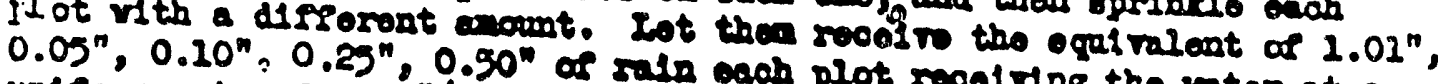

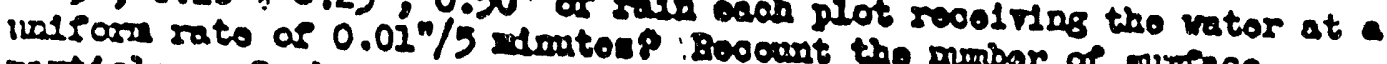

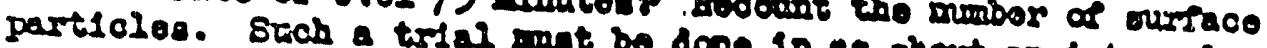

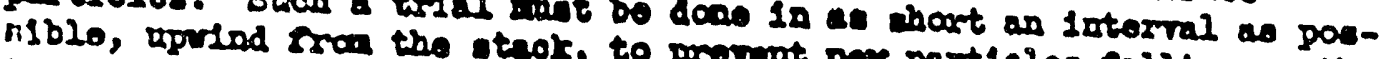
tost plote.

2. If thoro has boon an change in the muber of surface parte af the abore plote, then las ant articion is abs

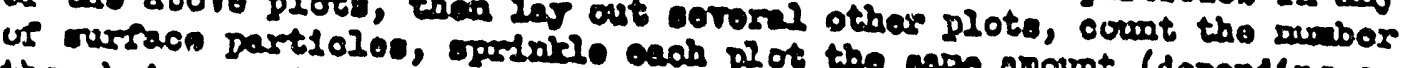

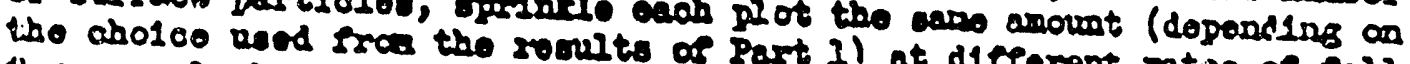

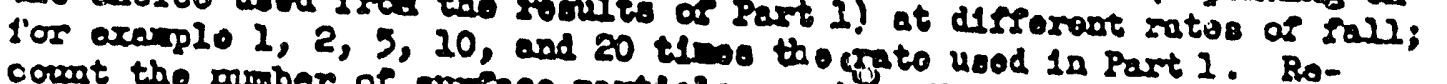

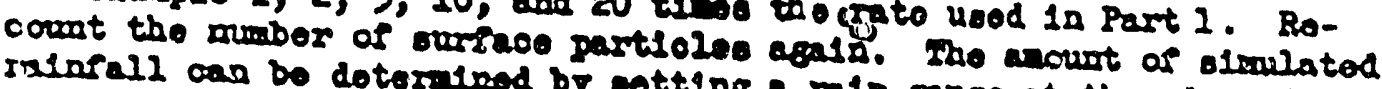
rainfall can bo dotermined by pottlog a raln gange at tho odfo of of (procipitation as the toot plot 1e recol ving).

\section{Pooglale Solats.n}

Bocensos particles fall at all bours, :

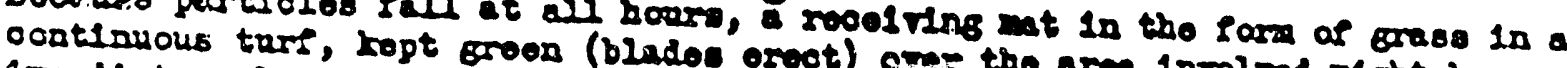

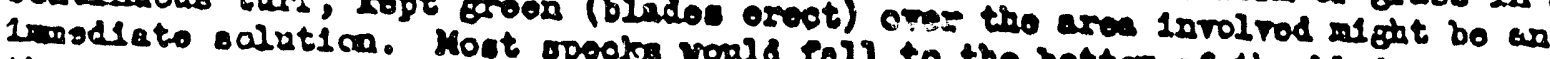
thos roold not bocoin al rbarne.

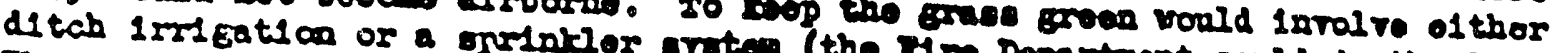

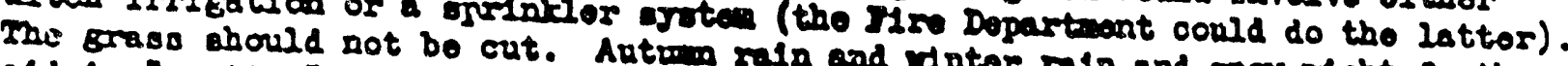
ald in "rootiog" the opocke.

P. 2. Cburah

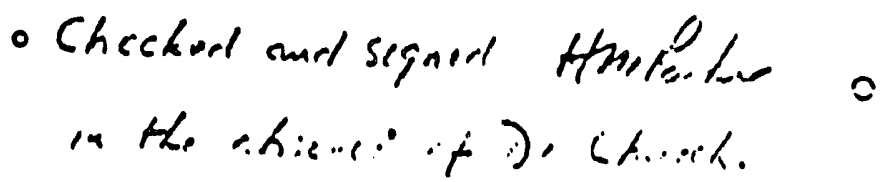

\section{(1)}

$$
\text { o. }
$$

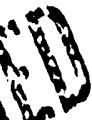



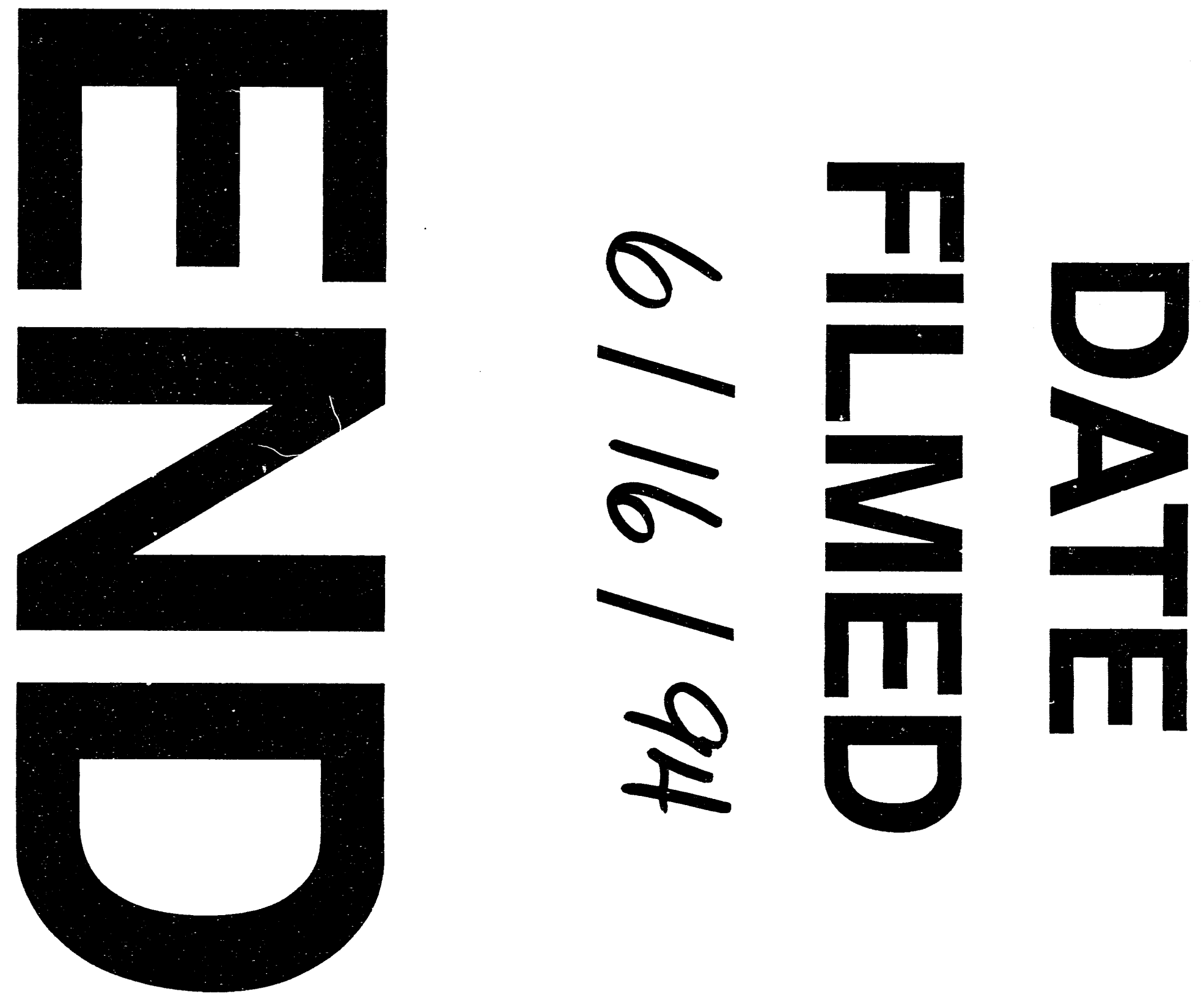
- 